\title{
Literary Texts in the EFL Classrooms: Applications, Benefits and Approaches
}

\author{
M Shamsur Rabb Khan ${ }^{1 *}$, Ali Mohammad Alasmari ${ }^{2}$ \\ ${ }^{I}$ Department of English, Deanship of Community Service and Continuing Education, King Khalid University, Abha, \\ Kingdom of Saudi Arabia \\ ${ }^{2}$ Deanship of Community Service and Continuing Education, King Khalid University, Abha, Kingdom of Saudi Arabia
}

Corresponding Author: M Shamsur Rabb Khan, E-mail: samsur.khan@gmail.com

\section{ARTICLE INFO}

Article history

Received: March 17, 2018

Accepted: May 12, 2018

Published: September 01, 2018

Volume: 7 Issue: 5

Advance access: July 2018

Conflicts of interest: None

Funding: None

\begin{abstract}
Literary texts play an important role in learning English language, especially enhancing communication competence, raising cultural awareness, and generating motivation among students. Research studies have shown the potential advantages of using literary texts in the EFL classrooms, which promote authentic materials, help increase language skills, and extends linguistic knowledge. This paper documents comprehensive literature on the application and benefits of literary texts in learning and teaching English language to EFL learners. It explains how different language skills can be learnt successfully using literary texts. This paper shows the significance of literary texts in English language teaching program. It explores the historical background, covering various phases, studies from various countries, including the Arab world where literature teaching shows positive responses. The paper is distinct in its entirety since it explains how different literary texts can help enhance language skills and describes the different teaching approaches for teaching literature which will be a healthy guide for teachers. It also shows how literature enriches the EFL learners' overall learning experience.
\end{abstract}

Key words: Literature, EFL, Short Story, Language Skills, Poem, King Khalid University

\section{INTRODUCTION}

In English as a Foreign Language (EFL) teaching, literature is instrumental in engaging students' minds and feelings in meaningful communication in English (Sage,1987). Moody (1971) noted that "the study of literature is fundamentally a study of language in operation" and "literature can fit into virtually any language methodology ". The language of literature is usually normal since it is the normal language which becomes elegantly poetic (Carter 1999; Hall, 2001). Balakian (1977) highlighted that "literary language bridges the subjective state and the physical reality of the outside world". Collie and Slater (1990) suggested four essential reasons: profitable and authentic material, language enrichment, personal involvement and cultural improvement. Maley (1989) offered some fundamental reasons for the use of literature in language classroom while C S Lewis proclaimed: "literature adds to reality, it does not simply describe it. It enriches the necessary competencies that daily life requires and provides ... it irrigates the deserts that our lives have already become" (Holmer, 1976). Literature can offer much to the language learning because it familiarize the learners with natural language, or simply 'language at its finest' (Ghosn, 2002).

E M Forster (1962) lauded thus: "What is wonderful about great literature is that it transforms the man reads it towards the condition of the man who wrote" while Povey
(1972) asserted: "literature will help increase language skills because literature will extend linguistic knowledge by giving evidence of extensive and subtle vocabulary usage and complex and exact syntax". Other studies (Bassnett \& Grundy, 1993; Carter \& Long, 1991; Carter, Walker, Brumfit, 1989; Collie \& Slater, 1987; Brumfit and Carter, 1986; Gower \& Pearson, 1986; Maley \& Moulding, 1985; and Carter \& Burton,1982) provided theoretical basis for effective use of literature in EFL classroom. Bassnett and Gundy (1993) argued that literature illustrates language usage as the sublime skill while Allen (1978) compared the tie-up between language and literature thus: "If human experience is the what of literature then surely language is part of the how".

This paper shows the significance of literary texts in English language teaching program. It explores the historical background, covering various phases, studies from various countries, including the Arab world where literature teaching shows positive responses. The paper is distinct in its entirety since it explains how different literary texts can help enhance language skills and describes the different teaching approaches for teaching literature which will be a healthy guide for teachers. It also shows how literature enriches the EFL learners' overall learning experience. 


\section{HISTORICAL BACKGROUND OF TEACHING LITERATURE}

\section{Phases of Literature Teaching}

Eagleton (1996) argued that the concept of literature encompassed the entire gamut of valuable writing on history, poetry, philosophy, essays and letters, etc. According to Hall (2005), the University College London established the first Department of English Literature in 1828, and the first Departments of English at Oxford and Cambridge were founded in 1849 and 1878 respectively. Kramsch \& Kramsch (2000) summarized the phases of literature teaching thus: "Throughout the $20^{\text {th }}$ century, literature has been given many purposes in language study: aesthetic education of the few (1910s), for the literacy of the many (1920s), for moral and vocational uplift (1930s-1940s), for ideational content (1950s), for humanistic inspiration (1960s-1970s), and finally for providing an (authentic) experience of the target culture (1980s-1990s)". Tayebipour (2009) reported that literature, with the exception of Grammar-Translation Method period has been Cinderella, and treated like a redundant subject. Hence, during 1940s and 1960s literature almost disappeared from the language curriculum (Carter, 2000).

During 1960 and 1980s, there was hardly any substantial research on the effectiveness of literature in language teaching was undertaken because Functional-Notional Method sidelined literature for its paucity on communication competence while Structural Approaches downgraded literature as an old-fashioned tool (Llach, 2007). Topping (1968) wanted literature to be completely excluded from the EFL curriculum because it did not help in enhancing linguistic proficiency among EFL learners. The historic division between literature and language which Short (1996) called a 'border dispute over territory', paved the way for teaching of language and literature as two 'disconnected pedagogic practices' (Carter and McRae, 1996).

After analyzing the 1954-1998 Northeast Conference Reports, Davis (2000) placed 1967 as a watershed year when language teaching was divided into two: teaching of literature and teaching of language. Hall (2005) called Baldick (1983), Doyle (1989) and Palmer (1965), a as the leading researchers who provided the best works till date on languages and literatures for the first language learners".

In the beginning of the $20^{\text {th }}$ century, the relationship between literature and language "was excellent" but then the notion "literary language was superior to spoken language" changed the scenario and literature was left out of the language programmes (Larsen-Freeman, 2000). In the 1980s, researchers focused on teaching language skills via literary texts which would help learners "interact, express, negotiate, and provide personal interpretations (Harper, 1988). The advent of Communicative Language Teaching (CLT) approach saw the reintroduction literature because literary texts offered real, cultural and pleasurable materials to the learners (Hall, 2005). Moreover, research on the value of reading was done the 1980s which promoted 'reader response' approaches to use literary texts in language classes (Hirvela 1996; Elliott, 1990).

\section{Research Studies in Arab World}

However, in the Arab region, there were no research studies to showcase the effectiveness of literature in language teaching. Issues such as benefits and losses, cultural barriers, usefulness, methods, models and attitudes of students in learning English language through literature have been explored (Obeidat, 1996 \&1997; Asfour, 1983; Adam et al, 2015; Shaaban, 2015; Shakfa, 2012; Tehan et al, 2015; Babaee et al, 2014; Lakshmi \& Jayachandran, 2012; Paesani, 2011; Ögeyik, 2007; Yilmaz, 2012; Hişmanoğlu, 2005; Erkaya, 2003; Ceylan, 2016; Gencer et al, 2011; Muhammed, 2013; Ghouti et al, 2014; Dahiyat, 1983; Zid, 2015; Al-Mahrooqi, 2012).

In Saudi Arabia, various studies have shown the role, factors, approaches and benefits of literary texts in English language classrooms, (Alfauzan et al, 2016; Alsaeed, 2013; Al-Jabry et al, 2014; Abdulmughni, 2015; Yadav, 2014; Alsaeed, 2013; Lakshami \& Jayachandran, 2014; Choudhury, 2015; Ahmad, 2014). In Iran, studies on significance, effect, advantages and suggestions on using literature to enhance language skills have been illustrated (Khatib et al, 2011; Tayebipour, 2009; Aghagolzadeh, 2012; Khatib et al, 2011; Khansir, 2012; Khatib et al, 2013; Keshavarzi, 2012; Rezanijad et al, 2015; Mohammdzadeh, 2009; Alemi, 2011; Yarahmadi, 2016).

In non-Arab regions, problems, attitudes, methodologies, functions, and usefulness of using literary texts in EFL classroom have been studies by (Fogal, 2010; Ghazali et al, 2009; Cohen, 1968; Nuzzaci et al, 2016; Giuria, 2015; Hernndez, 2011; Bobkina, 2014; Olsbu, 2014; Erdem, 2016; Ussa, 2013; Savvidou, 2004; Krishnasamy, 2015; Ansari, 2013; Choudhary, 2016; Tungesh, 2011; Zhen, 2012; Armstrong, 2015; Tasneen, 2010; Shazu, 2014; Mohammadzadeh, 2009; Tseng, 2010; Chen, 2014; Daskalovska et al, 2012; Krsteva et al, 2014; Hwang et al, 2007; Aziz et al, 2010; Rashid et al, 2010; Babee et al, 2014; Khalid, 2012).

\section{ROLE OF LITERATURE}

"Literature is an ally of language", claimed Brumfit and Carter, (1986) and Mckay (1982) pronounced that "literature presents language in discourse". For Carter \& Long (1991), the study of literature is "a sine qua non for the truly educated person". Literary language is helpful for learning a language since the important purpose of it is "the revelation of creativity, of the knowledge of the self and of others manifested by that language used in literary context" (Balakian, 1977). Literature can best depict people and places, situations and scenarios, including stimulation that learners can understand since literature depicts universality (Sage, 1987).

During 1960-80, ELT approaches questioned the application of literature in the EFL/ESL classroom, but Zafeiriadou (2001) observed that "theoretical principles obviously go right back to the early $20^{\text {th }}$ century» when scholars like Saussure (1916), Baldick (1996) and Richards (1929) advocated the contribution of literature. Barthes $(1975,1977)$, Isher (1974), Eco (1979, 2005), Fish (1981) and Leech and Short (1986) provided important works to back it up. Practical 
teaching applications were offered by Bassnet \& Grundy (1993), Lazar (1993), McRae (1992), while Widdowson (1975) produced "ground-breaking work on the textbooks" and Simpson (1993, 1996, 2004) and Toolan (1998) added works to carry forward the application of literary texts in language teaching. Spack (1985) lauded literary texts in producing more culturally-tolerant language learners.

In 1980 s, the role of literature in language teaching attained greater significance because of the publication of numerous integrated texts on the subject (McRae \& Pantaleoni 1990; Maley \& Duff 1990; Duff \& Maley 1990; Collie \& Slater 1987; Carter \& Long 1985; Boardman \& McRae 1984)). In the 1980s and 1990s, books such as Making Headway Literature (1992) by Bill Bowler and Sue Parminter, Teaching Literature (1991) by R Carter and M Long, Past into Present (1990) by R Gower, The Web of Words (1987) by R Carter and M Long, A Course in Language and Literature (1986) by B Lott, and Language for Literature (1983) by $\mathrm{R}$ Walker laid the foundation for using literature into EFL class.

\section{Two Positions on the Role of Literature}

Scholars highlighted two positions - essentialist and non-essentialist - on the usefulness of literature in language learning (Yuksel, 2007; Donato \& Brooks, 2004; Scott \& Tucker, 2002; Edmondson, 1997). The essentialist position argued that teaching literature can make language learning easier (McKay, 1982; Widdowson, 1984; Lazar, 1993), instill cultural knowledge (Ghosn, 2002; Parkinson \& Thomas, 2000; Shanahan, 1997; Lazar, 1993, 1994; McKay, 1982), promote analytical thinking (Ghosn, 2002; Parkinson \& Thomas, 2000; Lazar, 1993) and invigorate motivation (Ghosn, 2002; Parkinson \& Thomas, 2000; Lazar, 1993; McKay, 1982) in EFL/ESL classroom. The non-essentialist position, on the other hand, considered nil or very limited use of literature in language learning. They argued that "it is not essential to handle literature in the interest of developing L2 proficiency" (Yuksel, 2007).

In developing different aspects and skills of English language, the role of literature is multi-facet since it promotes knowledge of vocabulary, phrases and specified expressions (MacKenzie, 2000; Frantzen, 2002), knowledge of grammar (Atmaca et al, 2016; Tayebipour, 2009), awareness of language (Carroli, 2008), pragmatic and sociolinguistic proficiencies (McKay, 2001), educational, linguistic and psychological competencies (Carter \& Long, 1991) and emphasis culturally authentic literary texts into EFL curriculum (Dupuy, 2000; Swaffar, 1999). Hall (2005) identified literature "as potentially playing a role in facilitating the learner's access to English language". In EFL class, literary texts are significant for both learning language and accomplishing educational goals (Bredella, 2000; Widdowson, 1992). Literature is regarded as "the highest form of expression of the target language" (Gilroy and Parkinson, 1996).

\section{Principle Bases for Incorporating Literature}

According to, Duff and Maley (1990), as quoted by Savvidou (2004), principal bases for incorporating literature in the EFL classroom are: linguistic, methodological and motivational. Short and Candlin (1986) stated: "if literature is worth teaching qua literature, then it seems axiomatic that it is the response to literature itself which is important". The systematic study of vocabulary, structure, register, the stylistic features of a text, are meant to explore "not just what a text means, but also how it comes to mean what it does" (Short, 1996). Lazar (1993) suggested following five reasons for integrating literature in ELT:

1. Expanding students' language awareness

2. Encouraging language acquisition

3. Developing students' interpretative abilities

4. Motivating materials

5. Educating the whole person.

\section{BENEFITS OF USING LITERATURE}

Mckay (1982) listed three major benefits of using literature: it fosters learners' reading skill; it promotes tolerance; and it helps learners become creative. Literature motivates learners towards personal and dynamic learning (McRae, 1991). Research studies have explored the potential benefits of integrating literary texts in the language classroom (Edmonson, 1997; Carter and McRae, 1996; Kramsch, 1993; Lazar, 1993; Widdowson, 1992; 1989; Carter et al., 1989; Maley and Duff, 1989). If Kim (2004), Yang (2001), Belcher and Hirvela (2000) and Gilroy and Parkinson (1997) explained the methods to incorporate literary texts in EFL classroom, Denka (2005), Hall (2005), Keunen and Eeckhouf (2001), and Schröder (1977) investigated the place of literature in language learning. Carter and Stockwell (2008), Paran (2008) and Parkinson and Thomas (2000) described comprehensive classroom practices and practical teaching narratives. Frye (1964) claimed that literature provides encouragement of tolerance, promotion of creativity and transfer of imaginative energy to students. Moon (2000) argued that literature helps enhance learners' interests and involvement, stimulates their critical thinking, and transform the entire teaching process into a lively exercise.

\section{Broad Benefits of Literature in Language Learning}

Maley (2001) opined that literature, as an ideal tool, develops creative comprehension and enhances the communicative competence of learners. Arthur (1968) discussed three processes of language learning through literature: syntactic pattern, large stock of vocabulary, and knowledge of other cultures. Povey (1972) pointed out subtle vocabulary usage and promotion of language use for communication. Maley (2001) mentioned the following seven broad benefits of literature in language learning:

- Universality

- Non-triviality

- Personal Relevance

- Variety

- Interest

- Economy and Suggestive Power

- Ambiguity.

Some studies pointed out benefits of using literature like dimension of depth, liberal thinking, special depth and 
human qualities (Sánchez, 2008; McKay, 2001; Stevick, 1976; Burke and Brumfit, 1986). Literary texts act as a model for language learners to get acquainted with various forms and conventions of a language (Ur, 1996; Collie and Slater, 1991). Literature enriches the skills of learners to critically examine discourse presented in different cultural and social contexts (Savvidou, 2004). More importantly, literature helps learners in their intellectual and personal growth since they begin to know and value other cultures, societies and ideologies (Carter and Long, 1991). Parkinson and Thomas (2000) listed the following ten benefits of literature:

1. Linguistic Model

2. Linguistic Competence

3. Cultural Enrichment

4. Authenticity

5. Mental Training

6. Memorability

7. Rhythmic Resource

8. Motivating Material

9. Open to Interpretation

10. Convenience.

\section{LEARNING LANGUAGE SKILLS THROUGH LITERATURE}

Studies on how literature affects language learning explored skills, level of usage, linguistics knowledge, language practice and communication competence Povey, 1972; Lee, 1970; Moody, 1971; Parkinson and Thomas, 2000; Widdowson, 1978; Brown, 2000; Simpson, 1997; Ali, 1993; Davis, 1989; Tomlinson, 1998; Liaw, 2001; Fish, 1980; Rosenblatt, 1978; Tutas, 2006; Hirvela, 1996; Kellem, 2009).

\section{How Literature Enhances Listening}

Listening is a dynamic activity but twice as hard as speaking. According to Mckay (2001), literature provides a perfect setting for enhancing listening skills as it familiarize learners with a variety of voice qualities and dialects. Jacobs (1990) recommended that learners should be provided with listening opportunities of literary texts which help them get engaged - both intellectually and emotionally. In EFL classroom, reading out to learners on a regular basis is better than other language learning activities (Hall \& Williams, 2000). Stories and children's books stimulate learners to create visual images in their minds, which lead them to remember the events of the story, characters, and sequence with utmost accuracy (Aiex, 1988; Raines \& Isbell, 1989; Hoag, 1996; Trelease, 1996; Hall \& Williams, 2000; Miles, 2002).

"Using literature will help students develop an awareness of the beauty in the rhythm and sound of language, and how to visualize characters, settings, moods and situations while listening" (Hoag, 1996). Stephens and Brown (2000) suggests that "a teacher read-aloud meets the objectives of the lesson. Its purpose is to create interest and curiosity about the selection among students. Hence, read-aloud, listening guides, readers' theater, and listening logs provide students with a heightened involvement with literature. Storytelling immensely help develop learners' listening skills. In the post-listening session, the students tell stories to classmates, and in the process each learner gets an opportunity to listen to each one (Paley, 1990; Jalongo, 1995; Hoag, 1996).

\section{How Literature Stimulates Speaking}

Widdowson (1994) argued that "speaking is the active production skill and use of oral production. It is the capability of someone to communicate orally with others". Khamkhien (2010) believed that "speaking is considered to be the most important in a second language". In the literature class, question-answer, debate, and role play are some of the effective activities to improve the students' speaking skill. Harmer (1984) reported: "since there were stimulations activities in the classroom for motivating the students, they get the self-confidence of being of part in the classroom including answering the question, sharing the idea, and also presentation".

According to Bygate (1987), "speaking is the vehicle "par excellence' of social solidarity, of social making of professional achievement and of business. Yet, speaking is in many ways an undervalued skill... which deserves attention". Stevick (1996) observed: "ease of speaking is not just nice; it is also useful". McKay (2001) said that "because literary texts depend on how the language is used to create a particular effect, literature demonstrates for learners the importance of form in achieving specific communicative goals". As per Collie and Slater (1987), "literary texts serve as an excellent prompt for oral work, as they provide unexpected compactness of meaning leading to a variety of interpretations through imagination and discussion".

\section{How Literature Promotes Reading}

Numerous studies show how literature promotes reading development and achievement (Cohen, 1968; Chomsky, 1972; DeFord, 1986; Galda \& Cullinan, 2003). Literary texts exert positive influence on learners' attitudes and perceptions on reading (Eldredge \& Butterfield, 1986; Larrick, 1987). Literature impacts writing skill (Lancia, 1997; Eckhoff, 1983; DeFord, 1981, 1984). Langer (1997) opined that reading literature can open "horizons of possibility, allowing students to question, interpret, connect, and explore".

Mckay (1982) argued that literature helps promote reading skill. For Widdowson (1979), reading is "not as a reaction to a text but as interaction between writer and reader mediated through the text." Yopp \& Yopp (2013) provided various 'pre, during and post-reading activities, while Rosenblatt (1978) offered two reading methods: efferent (a reading whereby the learners is concerned with language skill) and aesthetic (learners' feeling of inner joy). Brumfit and Carter (1986) reported: "reading literary texts will help our students to understand and appreciate multiple levels of meanings, metaphors and phonological patterning in many other types of texts".

\section{How Literature Inspires Writing}

Stern (2001) stated that literature is a rich source of inspiration for writing in EFL/ESL - both as a subject matter and 
as a model. Readers of literature are motivated to imitate the original writing, its theme, content and style, and at the same time readers show original thinking when they analyze and interpret texts. Many students of literature metamorphosed into a highly creative writers Classroom activities such as discussion or exercises after text comprehension reading motivate students to analyze, interpret and criticize the work of literature (Stern, 2001). Various contents, themes, styles and organizations of literary works help generate original thinking among learners which they tend to write (Hişmanoğlu, 2005).

Literary texts are rich sources of figurative language, beautiful sentences, idiomatic expressions, interesting proverbs, and suitable vocabulary items filled with connotative meanings. In addition, range of vocabulary, grammatical structures and style of writing woven into a gripping narration enthrall the readers. According to Custodio and Sutton (1998), literature provides motivation among learners to explore, to ask, or to criticize. Vandrick (2003) asserted that learners will be exposed to different language patterns to see how sentences and paragraphs can be put together.

\section{Exploiting Short Stories for Language Learning}

Since "the world of short fiction both mirrors and illuminates human lives" it attracts immediate attention of learners (Sage, 1987). Murdoch (2002) argued that "short stories can, if selected and exploited appropriately, provide quality text content which will greatly enhance ELT courses for learners. Kilpatrik et al (1994) opine that "through the power of imagination we become vicarious participants in the story. We literally 'identify' ourselves with our favourite characters, and thus their actions become our actions".

Oster (1989) argued that short story is a powerful and motivating factor for teaching four skills, for example, teacher-oral reading, role-play, enactment of characters, dramatic presentation, interpretation, and discussion can lead the learners enhance their language. According to Collie and Slater (1991), short stories are beneficial because of:

- $\quad$ its short length;

- $\quad$ its clarity and simplicity;

- $\quad$ its different tastes and interests; and

- $\quad$ its vast and varied topics.

According to Pardede's (2011), a great number of English language trainers found short stories as fascinating to be used both as texts for individual enjoyment and as model for language classrooms. Spack (1985) suggested that the language teacher should select short stories which can be interesting for learners. According to McKay (2001) and Rivers (1968), if a literary text is relevant to their life experience and interests, learners do read and enjoy it. Morgan and Rinvolucri (1983) provided range of classroom exercises and more than 70 storylines ('skeletons') for learners.

\section{Using Poetry for Language Learning}

According to Maley and Duff (1989), “poetry offers a rich resource for language learning. A poem offers a readymade semantic field for learners to enter". Benton et al (1987) affirmed "the main objective of using poetry in language lessons is to find a means of involving the learners in using their language skills in an active and creative way". Bagherkazemi and Alemi (2010) claimed that poetry "engages the reader in interpretation, meaning negotiation and the generation of coherent discourse-based meaning". Widdowson (1992) said that poetry offers value-added understanding of other cultures while Hanauer (1997) suggested two theories for understanding poetry: formalist and conventionalist. While the former talks of learning the basic characteristics of poems the latter deals with 'conventions of reading related to poetry'. Roman Jakobson (1960) proposed the following six crucial functions for language used in a poem:

- Emotive

- Referential

- Phatic

- Conative

- Metalingual

- Message.

"Teaching reading, and writing, as quoted in Sage (1987), "has been successfully defended over the centuries by Sir Philip Sidney (1554-1580), S. T. Coleridge (1772-1834), and T.S. Eliot (1888 1965)". From a wider educational perspective, poetry possesses a special artistry to boost learners' emphatic attitude and fashion their emotional life. (Paran, 2008; Hall, 2005; Belcher \& Hirvela, 2000; Gilroy \& Parkinson, 1997). Hanauer (1997) argued that "the reading of poetry is a task in which the discussion of meaning inherently involves a consideration of form". Sage (1987) listed five benefits of poetry: (a) linguistics; (b) educational and learning; (c) cultural; (d) emotional; and (e) esthetic. According to Maley and Moulding (1985), "If carefully selected, poems can open up themes which are common to us whatever our cultural background, and can thus act as a powerful stimulus to the students' own reflective thinking. Sarac (2003) listed the following educational benefits of poetry:

(a) it presents a language use which is different;

(b) it stimulates readers to react and analyze; and

(c) it makes readers familiar with figures of speech.

Lazar (1993) explored various teaching activities like brainstorming word associations, speculating the symbolic meaning of a word and writing clusters of figurative meanings. Collins (2012) offered the following five strategies to study poetry:

(1) Discussion-director: a process of writing questions related to a poem to be discussed;

(2) Passage-picker: selection of difficult sentences from text containing figurative language;

(3) Word-finder: investigation of meaning of tough words;

(4) Connector: connection of the themes of a poem with personal experience of learners; and

(5) Reporter: questions raised during teaching and group mind map.

\section{Utilizing Drama for Language Learning}

Drama makes learners to become active participant who experience similarity in language use in the classroom to that of real-life. Abdulmughni (2016) argued that "drama is the 
most appropriate to teach speaking skills. It is a recreation of real life dialogue. It utilizes all of the communication skills". "Drama can be used to bring literature to life for the students. It is more dynamic than simple text and helps the visual learners as well as recycles new vocabulary" (Boudreault, 2010). Drama and language games introduce natural dramatic activities like ice-breakers, energizers, brain-teasers, improvisation and role-play which provide similar experiences (Davies, 1990). Drama guides learners to comprehend the experiences of their life and contemplate specific situations and through a deeper linguistics world (Sarıçoban 2004). According to Lenore (1993), drama helps:

- In creative thinking;

- In developing language development;

- In enhancing listening skills;

- Teachers with renewed outlook for teaching;

- In creating a light classroom atmosphere; and

- Understand the problems in other cultures.

Drama reveals the aspects of both theory and practice of how English language is used in various perspectives (Whiteson,1996). Learners get engaged in learning process and they try to express themselves in the language of the character.

\section{APPROACHES TO TEACHING LITERATURE}

According to Moody (1983), an approach aims to "provide a framework, or sequence of operations to be used when we come to actualities". Richards and Rodgers (1986) argued that different types of activities form the basis for different philosophies at the level of teaching approach. For Duppenthaler (1987), an activity is "anything that is designed to increase students' motivation, participation in the learning process and the interaction between learners". Whitehead (1968) suggested that teachers must have the knowledge of various approaches and techniques for making literature teaching a success. Among many, some of the approaches to teach literature are discussed below.

\section{The Critical Literary Approach and the Stylistic Approach of Maley}

Maley's (1989) offered two approaches: the critical literary approach (the study of literature as a cultural artifact), which focuses on background, plot, literary concepts, motivation, characterization, psychology and value etc., and the stylistic approach (the study of literature as a resource for learning language), which focuses on description of text, analysis of language and critical interpretation. While the critical approach requires expertise in linguistics the stylistic focuses on linguistic competence without covering the teaching needs about four language skills.

\section{Three Models of Carter and Long}

For teaching literature, Carter and Long's (1991) suggested three models - the language model, the cultural model and the personal growth model. The cultural model focuses on providing knowledge of historical background, authors, cultural trends, and certain periods. The language model focuses on developing four skills, i.e., listening, speaking, reading and writing, in addition to motivating learners to become creative in language use. The personal growth model aims at students' growth as individuals by inculcating imagination, creativity, critical thinking, and aesthetic taste in their personality.

\section{Six Approaches of Van}

Van (2009) offered the following six approaches:

1. The Stylistic Approach

2. The Reader-Response Approach

3. The Language-Based Approach

4. The Critical Literacy Approach

5. New Criticism

6. Structuralism.

According to Simon (2006), Stylistic Approach "considers literature primarily as discourse and studies it from a linguistic perspective, which means, how literary texts exemplify the system of language". Widdowson (1989) explained that "the purpose of stylistic analysis is to investigate how the resources of a language code are put to sue in the production of actual messages".

The Reader-Response Approach considers literature as interaction between the text and the reader or what changes occur in reader's mind in going through a text, not as lingual objects printed on a page. Eco (1984) observes that "the reader as an active principal of interpretation is a part of the picture of the generative process of the text".

According to Van (2009), the Language-Based Approach considers literature as "an excellent vehicle for CLT methods that result in four-skill English language development through interaction, collaboration, peer teaching, and student independence". Carter (1988) believed role play, poetry debate, cloze, prediction and ranking tasks should be used for language learning (Carter, 1996; Rosli, 1995). This approach is more practical than other ones (Littlewood, 1986; Carter, Long, 1991)).

Critical Literacy motivates students to learn how texts are associated with issues of class, culture, identity, gender, ethnicity, religion and political power. Osborn (2000) argued that "literary truth revealed as knowledge is the manifestation of myriad relationships. The teaching of language has far has failed to addresses how literature tackle dominant problems of ideology and power relations in society (Cummins 2000; Comber 1994).

The New Criticism puts much attention on close reading, especially of poetry to explore how literary text works as self-referential, self-centered aesthetic piece to be interpreted by readers. Ogden and Richards (1923) said: "in literature there are intertwined two distinct kinds or levels of art - a generalized, non-linguistic art, which can be transferred without loss into an alien linguistic medium, and a specifically linguistic art that is not transferable".

Barry (2002) showed that the proponents of structuralism analyze a piece of prose narrative vis-à-vis other related text including the following structures:

- a set of intertextual connections;

- a set of conventions of a particular literary genre; 
- a notion of narrative as a complex of recurrent patterns of motifs; and

- a designed model of an underlying universal narrative structure.

\section{Wellek and Warren's Intrinsic and Extrinsic Model}

Wellek and Warren (1994) presented two approaches: intrinsic and extrinsic. in intrinsic approach, reader focuses on the structure, language, form, images, symbols, style, contrasts, and growth of a plot in a literary text. The extrinsic approach focus is directed to the biography of the author, historical background, and social aspects. In intrinsic approach, following levels are explored:

- grammatical

- lexical

- $\quad$ structural

- cultural.

The major focus of extrinsic approach are:

- biographical

- historical

- aesthetic

- philosophical.

\section{Four Methods of Durant (1995)}

Durant (1995) stated four methodological approaches to teaching literature: lecture, informal dialogue, workshop and self-access learning. He provided the following activities in classroom:

- $\quad$ silent reading

- comprehension task

- Listening tasks

- Personal response

- Dictionary learning and study skills and dictionary work

- Talk in the target language

- Stylistic analysis

- Creative writing and written response.

\section{Integrative Approach to Literature Teaching}

Some known linguists and language teachers who offered integrated approach are Lucas (1990), Timuchin (2001), Amer (2003), Savvvidou (2004), Divsar \& Tahiri (2009), and Dhanapal (2010). They are discussed below.

\section{Lucas Text Type Approach (1990)}

Lucas (1990) divided texts into two major types: artistic and functional. Artistic texts include novels, short stories, essays, poems and plays. Functional texts consist of whatever texts other than the artistic as shown in Figure-1 below:

Functional text comprises six categories:

1. Casual texts include newspapers, magazines and non-fiction

2. Personal texts include letters and diaries.

3. Transactional texts include business letters, legal documents and reports.

4. Reference texts include dictionaries, catalogues, directories and inventories.

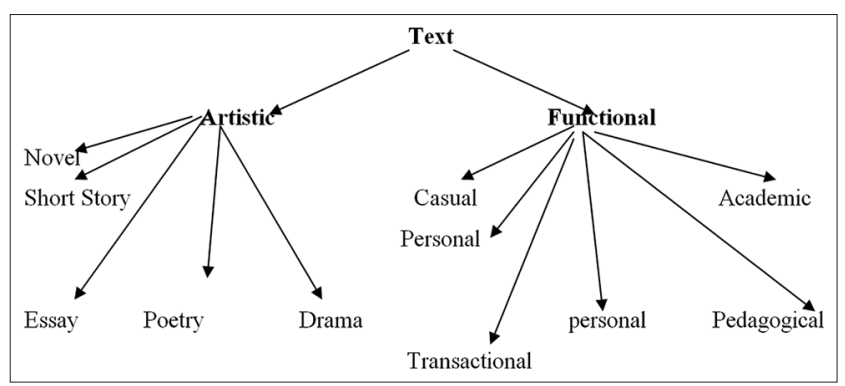

Figure 1. Lucas Classification of Literary Texts

5. Pedagogical texts include text books and encyclopaedias.

6. Academic texts include research papers, theses, specialist books and journals.

\section{Timucin's Integrative Approach (2001)}

Timucin (2001) integrated the stylistics and language-based approaches into a one pedagogical framework and noticed the benefits of this integrated approach vis-à-vis learners' engagement, liking for literary texts and enhanced motivation. This approach paved the way for further research on incorporating literature in language teaching.

\section{Savvidou's (2004) Integrated Approach}

According to Savvidou (2004), the following six-stage model can be employed to teach literary texts in language classroom:

- Stage 1: This is to elicit the students' literary knowledge on the context and themes of the text.

- Stage 2: This familiarizes learners with the text via reading and listening.

- $\quad$ Stage 3: This is directed towards learners' response to the literary text: spoken or written.

- Stage 4: This is focused on comprehension through intensive reading.

- $\quad$ Stage 5: This motivates learners to explore deeper into literary texts to analyze the text.

- $\quad$ Stage 6: This takes learners to individual understanding of the text followed by analysis.

\section{Divsar and Tahriri (2009) Integrated Approach}

According to Divsar and Tahriri (2009) literature as content or culture, literature as personal growth and language-based are three models for teaching literature. The researchers focused on three considerations: linguistic considerations, cultural considerations and communicative considerations as prerequisite for teaching literature. Following are the three phases for teaching literature:

1. The Preliminary Phase: This is language-based activities for developing comprehension.

2. The Content-cultural Phase: This makes learners know cultural aspects in the text.

3. The Synthesis Phase: This leads learners to evaluate the text and express their understanding. 


\section{Dhanapal's (2010) Integrated Approach}

Dhanapal (2010) integrated reader-response approach with stylistics analysis approach to address the critical and creative thinking skills upon Malaysian high school students. While "reader-response approaches would enlist a variety of interpretation but with stylistics in play, readers would follow some similar interpretive conventions". Figure-2 shows the Dhanapal's Integrated Approach.

\section{SELECTING LITERARY TEXTS}

For Mckay (1982), selecting appropriate literature is "the key to success in using literature in the ESL". The short, less complex, and have few characters are ideal literary texts for EFL learners. Nileson \& Donelson (1980) offered various books and materials for students and teachers. Honeyfield (1977) put emphasis on simplification of texts for producing a homogenized uniformity to dilute the information. Some scholars, quoted in Kramsch (2000), suggested to tailor the texts to the level of learners' competence. (Swaffar, 1985, 1988; Bemhardt (1986) pressed for making the task simple, not the text. Others called for 'reading for meaning' which means the text must be related to learners' cultural milieu not in the alien culture (Swaffar, Arens, \& Byrnes, 1991).

There are a number of books for the advanced level students offering useful activities to develop literary sensitivity through greater linguistic awareness (Short 1986; Durant and Fabb 1990; Widdowson 1992; Cook, 1994). Then there are collections of practically oriented articles by Carter et al. (1989) and Carter and McRae (1996) which would serve as an invaluable introduction to the area for trainee teachers or the uninitiated. Also, there are books for students at intermediate level (McRae and Vethamani 1999; Lazar 1993, 1999; Bassnet and Grundy 1993; McRae 1991, 1992; Carter and Long 1991; McRae and Pantaleoni 1990; Maley 1989, 1994; Duff and Maley 1990; Greenwood 1989; Tomlinson 1985, 1998; Collie and Slater 1987; Maley and Moulding 1986; Maley and Duff 1982, 1989).

For language teachers who use literature in the language classrooms, there are a number of books on style (Weber, 1996; Wales, 1989;) which offer a rich source of practical illustrations on form, genre, and style under the learner-centered teaching practice without ignoring the historical and social and historical of the literature (Toolan, 1998; Widdowson, 1975, 1992; Short, 1996; Carter \& McRae, 1996; Fowler, 1996; Simpson, 1993, 1997; Cook, 1994; Kramsch, 1993). Narrative and reading response theorists (Britton, 1990; Bruner, 1986; Rosenblatt, 1995, 1978; Scholes, 1989) do claim, and research confirms (Langer, 1995; Short, 1992; Wells, 1990) that literary texts must have the potential to generate quality discussion which reflect and explore intertextual connections.

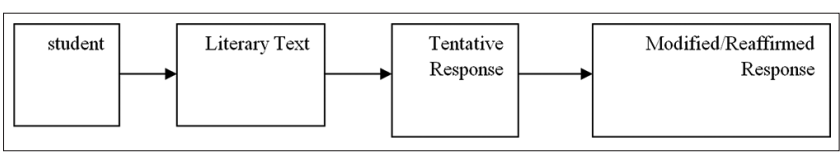

Figure 2. Dhanapal's Integrated Approach Process

\section{CONCLUSION}

This paper has illustrated the prospective advantages of using literary texts in the EFL classrooms. It is distinct in its entirety since it explains how different literary texts can help enhance language skills and describes the different teaching approaches for teaching literature which will be a healthy guide for teachers. It also shows how literature enriches the EFL learners' overall learning experience. For EFL teachers and learners, the paper offers examples of texts on styles and genres on literature for much better performance in the classroom

\section{REFERENCES}

Abdulmughni, Saleh, A. S. (2016). Teaching skills through literature. International Journal of Applied Linguistics \& English Literature, 5 (20) pp.10-16.

Adam, A. A. S., \& Babiker, Y. O. (2015). The role of literature in enhancing creative writing from teachers' perspective. English Language and Literature Studies, 5(1), 109-118.

Aghagolzadeh, F., \& Tajabadi, F. (2012). A debate on literature as a teaching material in FLT. Journal of Language Teaching and Research, (3)1, 205-210.

Aiex, N. K. (1988). Storytelling: it's wide-ranging impact in the classroom. Available at: https://www.ericdigests.org/ pre-929/wide.htm

Alfauzan, A., H. \& Abduljabbar G. Hussain. (2017). Attitude towards and perception of literature in EFL setting: A case study on QU male undergraduate students. English Language Teaching, 10(1), 1-17.

Alemi, M. (2011). The use of literary works in an EFL class. Theory and Practice in Language Studies, 1(2), 177-180.

Ali, S. (1994). The reader-response approach: An alternative for teaching literature in a second language. Journal of Reading, 37, (4), 288-296.

Al-Jabry, H., Mohammed, S., \& Abdul-Latif, A. (2014). Developing and piloting a literature course learnable via blackboard for EFL literature instruction. Studies in Literature and Language 8(1), 85-95.

Allen, V.F. (1978). Smite insights from linguistics for the teaching of literature. In: M.K. Burt \& H. Dulay (Ed.) New directions in second language learning, teaching and bilingual education. Washington: TESOL.

Al-Mahrooqi, R. (201). An investigation of literature teaching methodologies at a higher institution in Oman. TESOL Journal, 6, 172-180.

Amer, A. (2003). Teaching EFL/ESL literature. The Reading Matrix, 3 (2), 63-73.

Arıogul, S. (2001). The Teaching of Reading Through Short Stories in Advanced Classes. Unpublished M.A Thesis. Ankara: Hacettepe University.

Arthur, B. (1968). Reading Literature and Learning a Second Language. Language Learning, 28, 199-210.

Asfour, M. H. (1983). Cultural Barriers in Teaching English Literature to Arab students. Problems of Teaching English Language and Literature at Arab Universities. In: Eid A. Dahiyat \& Muhammad H. Ibrahim (Ed.). Amman: University of Jordan Press. 
Atmaca, H. \& R. Gunday. (2016). Using Literary Texts to Teach Grammar in Foreign Language Classroom. Participatory Educational Research (PER) 4, 127-133.

Babaee, B., \& Yahya, W. R. W. (2014). Significance of Literature in Foreign Language Teaching. International Education Studies, 7(4), 80-85.

Balakian, A. (1977). Teaching Language and Literature. Teaching Language Through Literature, 16, 1-5.

Baldick, C. (1983). The Social Mission of English Criticism, 1848-1932. Oxford: Clarendon

(1996). Criticism and Literary Theory, 1890 to the Present. London, New York: Longman.

Barthes, R. (1975). The Pleasure of the Text. New York: Hill and Wang.

(1977). Image-Music-Text. London: Fontana.

Barry, Peter (2002). Beginning Theory: An Introduction to Literary and Cultural Theory. Manchester University Press.

Bassnett, S., \& Grundy, P. (1993). Language through literature. London: Longman

Bernhardt, E. B. (1986). Proficient Texts or Proficient Readers? ADFL Bulletin, 18, 25-28.

Boardman, Roy. \& Mcrae, J. (1984): Reading Between the Lines. Cambridge: CUP.

Boudreault, C. (2010). The Benefits of Using Drama in the ESL/EFL Classroom. The Internet TESL Journal, 16 (1).

Bredella, L. (2000). Literary Texts. In Byram (Ed.) Routledge Encyclopedia of Language Teaching and Learning. London and New York: Routledge.

Britton, J. (1990). Talking to Learn. In: D. Barnes, 1. Britton, \& M. Torbe (Ed.). Language, the Learner and the School. Portsmouth, NH: Boynton/Cook.

Brown, H. Douglas, (2000). Teaching by Principles. US: Pearson ESL.

Brumfit, C.J., \& Carter, R.A. (1986). Literature and Language Teaching. Oxford: Oxford University Press.

Brumfit, C. J. (1983). Teaching Literature Overseas: Language-based Approaches. Oxford: Pergamon Press.

Bruner, I. (1986). Actual Minds, Possible World. Cambridge, MA: Harvard University Press.

Burke, S.J. and C.J. Brumfit. (1974). Is Literature Language? or Is Language Literature? English in Education: The Role of Literature, 8(2), 33-43.

Bygate, M. (1987). Speaking (Language Teaching: A Scheme for Teacher). Oxford: Oxford University Press.

Carroli, P. (2008). Literature in Second Language Education. London and New York: Continuum.

Carter, R. (1999). Common Language: Corpus, Creativity and Cognition. Language and Literature, 8 (93), 195216.

Carter, R. \& Burton, D. (1982). Literary Text and Language Study. London: Edward Arnold.

Carter, R. \& Long, M. (1991). Teaching Literature. Harlow: Longman.

Carter, R., \& McRae, J. (1996). Language, Literature and the Learner. Creative Classroom Practice. London: Longman.

Carter, R., \& Simpson, P. (1989). Language, Discourse and Literature. An Introductory Reader in Discourse Stylistics. London: Unwin Hyman.
Carter, R. Long, M. N. (1985): The Web of Words, Cambridge: CUP.

Essex: Longman.

Carter, R. (2007). Literature and Language Teaching 19862006: A Review. International Journal of Applied Linguistics, 17 (1), 3-13.

Carter, R. and Stockwell, P. (2008). The Language and Literature Reader. London: Routledge.

Carter, R., Walker, R., \& Brumfit, C. (1989). Literature and the Learner: Methodological Approaches. Modern English Publications and the British Counsel.

Ceylan, N. O. (2016). Using short Stories in Reading Skills Class. Procedia - Social and Behavioral Sciences, 232 (2016) $311-315$.

Chomsky, C. (1972). Stages in Language Development and Reading Exposure. Harvard Educational Review, 42, 1-39.

Choudhury, M. (2015). Text, Context and Motivational Strategies in Teaching Literature to Saudi Students. International Journal of English Language Teaching, 3(8), 19-35.

Cohen, D (1968). The Effect of Literature on Vocabulary and Reading Achievement. Elementary English, 45, 209-213.

Collie, J. \& Slater, S. (1987). Literature in the Language Classroom. Cambridge: Cambridge University Press.

(1987). Literature in the Language Classroom: A Resource Book of Ideas and Activities. Cambridge: CUP.

Collins, W., and Briganti, J. (2012). Cross-Cultural Poetry-Projects in a Japanese University EFL Setting, Athens: ATINER'S Conference Paper Series, No: LIT20120217.

Cook, G. (1994). Discourse and Literature: The Interplay of Form and Mind. Oxford: OUP.

Cummins, J. (2000). Language, Power, and Pedagogy: Bilingual Children in the Crossfire. New York: Multilingual Matters Ltd.

Custodio, B. and M. Sutton. (1998). Literature-Based ESL for Secondary School Students in TESOL Journal. 7(5), 19-23.

Dahiyat, E. A. (1983). Three Problems of Teaching English Literature to Arab Students at the University of Jordan. In: E. A. Dahiyat \& Muhammad H. Ibrahim (Ed.). Amman: University of Jordan Press.

Davis, J. N. (2000). Perspective on An Age: Forty-five Years of NECTFL Reports. In R. M. Terry (Ed.). Agents of change in a changing age. Lincolnwood, IL: National Textbook Co.

Davies, P. (1990). The use of drama in English Language Teaching. TESL Canada Journal8(1), 87-99.

DeFord, D. (1981). Literacy: Reading, writing, and other essentials. Language Arts, 58, 652-658.

. (1986). Classroom Context for Literacy. In: T. E. Raphall (Ed.). The Context of School-based Literacy. New York: Random House.

Denka, A. (2005). Lesestrategien und lesesteuerungsstrategien beim einsatz literarische texte im fremdsprachenunterricht. Lang: Frankfurt am Main. 
Dhanapal, S. (2010). Stylistics and Reader Response: An Integrated Approach to the Teaching of Literary Texts. Literacy Information and Computer Education Journal, 1 (4), 233-240.

Divsar, H. \&Tahriri, A. (2009). Investigating the Effectivness of an Integrated Approach to Teaching Literature in an EFL Context. Pan-Pascific Association of Applied Linguistics, 2 (13), 105-116.

Duff, A. \& Maley, A. (1990). Literature. Oxford University Press, Oxford.

Doyle, B. (1989). English and Englishness. London: Routledge.

Duppenthaler, P. (1987). Some Criteria for Selecting and Designing Activities for the Language Classroom. Modern English Teacher, 15(1), 36-37.

Dupuy, B. (2000). Content-based instruction: Can it help ease the transition from beginning to advanced foreign language classes? Foreign Language Annals (33), 205-223.

Durant, A. (1995). Introduction to 'Language Through Literature' Approaches to Teaching Literature in English in L2 Contexts. Sprak Och Fiktion. 291-311.

Durant, A. and Fabb, N. (1987). New Courses in the Linguistics of Writing. In Fabb, N, Attridge, D., Durant. A. and MacCabe. C. (Ed.) The Linguistics of Writing: Arguments between Language and Literature. Manchester: Manchester University Press.

(1990) Literary Studies in Action. London: Routledge.

Eagleton, T. (1996). Literary Theory: An Introduction. Blackwell: Oxford

Eckhoff, B. (1983). How Reading Affects Children's Writing. Language Arts, 60, 607-616.

Eco, Umberto. (1984). The Role of the Reader. Bloomington: Indian University Press.

Edmonson, W. (1997). The Role of Literature in Foreign Language Learning and Teaching: Some Valid Assumptions and Invalid Arguments. AILA Review, 12.

Eldredge, J.L., \& Butterfield, D. (1986). Alternatives to Traditional Reading Instruction. The Reading Teacher, 40, 32-37.

Elliot, R. (1990). Encouraging reader-response to literature in ESL situations. ELT Journal, 44, (3) 191-8.

Erkaya, O. R. (2005). Benefits of Using Short Stories in the EFL Context. Asian EFL Journal (8), 1-13.

Fish, S. (1981). Is There a Text in This Class? Cambridge, Mass.: Harvard University Press.

Fogal, G. G. (2010). EFL Literature Studies: Student Feedback on Teaching Methodology. Asian EFL Journal, 12(4), 61-76.

Forster E. M. (1962). Two Cheers for Democracy. California: Harcourt.

Fowler, R. (1996). Linguistic Criticism (2d ed.). Oxford: Oxford University Press.

Frantzen, D. (2002). Rethinking foreign Language Literature: Towards An Integration of Literature and Language At All Levels. In V. Scott, \& H. Tucker (Ed.). SLA and the Literature Classroom: Fostering Dialogues. Boston: Heinle\&Heinle.
Frye, N. (1964). The Educated Imagination. Indiana, Indiana University Press

Gajdusek, L. (1988). Toward Wider Use of Literature in ESL: Why and How. TESOL Quarterly (22), 227-254.

Galda, L. \& Cullinan, B.E. (2006). Literature and the Child. Belmont. CA: Wadsworth Thomson Learning.

Ghazali, S. N., Setia, P. Muthusamy, C. \& Jusoff, K. (2009). ESL Students' Attitudes towards Texts and Teaching Methods used in Literature Classes. English Language Teaching, 2(4), 51-56.

Ghosn, I. (2002). Four Good Reasons to Use Literature In Primary School ELT. ELT Journal, 56, (2), 172-179.

Gilroy, M. (1995). An Investigation Into Teachers' Attitudes to Using Literature in the Language Classroom. Edinburgh working papers in Applied Linguistics, 6, 1-17.

Gilroy, M. \& Parkinson, B. (1996). Teaching Literature in A Foreign Language. English Language Teaching, 29(04):213-225.

Gower, R., \& Pearson, M. (1986). Reading Literature. London: Longman.

Hall, G. (2001). The Poetics of Everyday Language. In J. McRae (Ed.). Reading Beyond Text: Processes and Skills. CAUCE, 24 Sevilla: Universidad deSevilla. (2005). Literature in Language Education. Basingstoke: Palgrave Macmillan.

Hall, D. Williams, E. (2000). The Teacher's Guide to Building Blocks. Greensboro, NC: Carson-Dellosa.

Hanauer, D. (2001). Focus-On-Cultural understanding: Literary Reading in the Second Language Classroom. CAUCE, Revista de Filología y Didáctica (24), 389-404. (2001). The Task of Poetry Reading and Second Language Learning. Applied linguistics, 295-323.

Harmer, J. (1984). The Practice of English Language Teaching. London: Longman.

Harper, S. N. (1988). Strategies for Teaching Literature at the Undergraduate Level. MLJ, 72, 402-414.

Hirvela, A. (1996). Reader-response Theory and ELT. ELT Journal, 50, (2) 127-34.

Hişmanoğlu, M. (2005) Teaching English through Literature. Journal of Language and Linguistic Studies, (1), 53-66.

Hoag, C.L. (1996). Appreciative Listening: The Forgotten Art. Overland Park, KS: The Writing Conference.

Holmer Paul L. (1976). C. S. Lewis: The Shape of His Faith and Thought. London: Sheldon Press.

Honeyfield, J. (1977). Simplification. TESOL Quarterly, 11(4), 431-440.

PegemAkademi. Iser, W. (1974). The Implied Reader. Baltimore: Johns Hopkins UP.

Jalongo, M.R. (1995). Promoting Active Listening in the Classroom. Childhood Education, 72(1), 13-18.

Jacobs, Leland B. (1990). Listening to literature. Teaching K-8, 20(4), 34-37.

Johnstone, B. (1996). The Linguistic Individual. Self-expression in Language and Linguistics. New York: Oxford University Press.

Keshavarazi, A. (2012). Use of Literature in Teaching English. Procedia - Social and Behavioral Sciences, 46, 554-559 
Keunen, B. \& Eeckhouf, B. (Ed.) (2001). Literature and Society. Lang: Bruxelles

Khamkhien, A. (2010). Teaching English Speaking and English Speaking Tests in the Thai Context: A Reflection from Thai Perspective. English Language Teaching Journal, 3(1), 184-200.

Khatib, M. (2011). A New Approach to Teaching Poetry to EFL Students. Journal of Language Teaching \& Research, 2(1), 164-169.

Khatib, M., Rezaei, R., Derakhshan, A. (2011). Literature in the EFL/ESL Classroom. English Language Teaching, 4(1), 201-208.

Khatib, M., Derakhshan, A., \& Rezaei, S. (2011). Why and Why not Literature: A task-based Approach to Teaching Literature. International Journal of English Linguistics, 1, 213-218.

Khatib, M. \& Seyyed, H.S. (2013). Short Story Based Language Teaching (SSBLT): A literature-based Language Teaching Method. International Journal of Basic Sciences \& Applied Research, 2 (2), 155-159.

Kilpatrik, W. Gregory. Wolfe, \& M, Suzanne. (1994). Books That Build Character: A Guide to Teaching Your Child Moral Values through Stories. Touchstone Rockefellert Centre. New York. Web.

Kim, M. (2004). Literature Discussions in Adult L2 Learning. Language and Education, 18(2), 145-166.

Kramsch, C., \& Kramsch. O. (2000). The Avatars of Literature in Language Study. The Modern Language Study, $84,553-573$

Kramsch, C. (1993). Context and Culture in Language Teaching. Oxford: Oxford University Press.

(1985). Literary Texts in the Classroom: A Discourse Perspective. MLJ, 69, 357-366.

(2013). Culture in Foreign Language Teaching. Iranian Journal of Language Teaching Research, 1 (1), 57-78.

Lakshmi, J., \& Jayachandran, J. (2012). Literature: An Effective Tool in Language Learning. Language in India, 12(2), 319-326.

Lancia, P.J. (19870). Literary Borrowing: The Effects of Literature on Children's Writing. The Reading Teacher, 50(6), 470-475.

Langer, J. A (1995). Envisioning literature: Literary Understanding and Literature Instruction. New York: Teachers College Press.

(1997). Literacy Acquisition through Literature. Journal of Adolescent and Adult.40, 602-614.

Larrick, N. (1987). Illiteracy Starts Too Soon. Phi Delta Kappan, (69), 184-189.

Larsen-Freeman, D., \& Cameron, L. (2008). Complex Systems and Applied Linguistics. Oxford: Oxford University Press.

Larsen-Freeman, D. (2000). Techniques and Principles in Language Teaching. Oxford: OUP.

Lazar, G. (1993). Literature and Language Teaching. Cambridge: Cambridge University Press.

Lee, W.R. (1970). Editorial. English Language Teaching, 25(1), 1-2.

Leech, G. and Short, M.H. (2007) Style in Fiction: A Linguistic Introduction to English Fictional Prose. London: Longman.
Lenore, K.L. 1993. The Creative Classroom A Guide for Using Creative Drama in Classroom. U.S.A.

Liaw, M. L. (2001). Exploring Literary Responses in an EFL Classroom. Foreign Language Annals 34 (1): 35-45.

Littlewood, W. T. (1986). Literature in the School Foreign-language Course. In Literature and Language Teaching, (Ed.). C. J. Brumfit and R. A. Carter. Oxford: Oxford University Press.

Llach, P. A. (2007). Teaching Language Through Literature: The Waste Land in the ESL Classroom. Odisea (8), 7-17.

Lucas, M., A. (1990). Four Important Factors in Reading. Forum, 28 (3), 26-30.

MacKenzie, I. (2000). Institutionalized Utterances, Literature, and Language Teaching. Language and Literature (9), 61-78.

Maley, A. \& Duff, A. (1989). The Inward Ear: Poetry in the Language Classroom. Cambridge University Press.

Maley, A., \& Moulding, S. (1985) Poem into Poem: Reading and Writing Poems with Students of English. Cambridge University Press. Cambridge.

Carter, R. Walker, R. \& Brumfit, C. (1989). Literature and the Learner: Methodological Approaches. Modern English Publications and the British Counsel.

Maley, A. (1989). Down from the Pedestal: Literature As Resource. In R. Carter, R. Walker \& C. Brumfit (Eds.). Literature and the Learner: Methodological Approaches. Modern English Publications and the British Counsel.

McRae, J., \& Pantaleoni, L. (1990). Chapter and Verse. Oxford: OUP.

McRae, J. (1997). Literature with A Small '1'. Hong Kong: Macmillan Publishers Limited

(1991). Applying the Buzzwords. Literature for Language Learners. British Book News 4,32- 37.

McKay. S. (1982). Literature in the ESL Classroom. TESOL Quarterly, 16 (4), 529-536.

(2001). Literature As Content for ESL/EFL. In M. Celce-Murcia (ED.). Teaching English As A Second or Foreign Language. Boston: Heinle \& Heinle.

Miles, K. (2002). Listen up! Parenting, 77(9), 126-132.

Mohammadzadeh, B. (2009). Incorporating Multicultural Literature in English Language Teaching Curriculum. Procedia Social and Behavioral Sciences, 1, 23-27.

Moody, H.L.B. (1983). Approaches to the Study of Literature: A Practitioner's View. In C. J. Brumfit (Ed.). Teaching Literature Overseas. British Council.

Moody, H.L.B. (1971). The Teaching of Literature in Developing Countries. London. Longman Group.

Moon, J. (2010). Using Story in Higher Education and Professional Development. Routledge Taylor \& Francis Group: London.

Morgan, J., and Rinvolucri, M. (1983). Once Upon A Time: Using Stories in the Language Classroom. New York: Cambridge University Press.

Murdoch, G. (2002). Exploiting Well-known Short Stories for Language Skills Development. IATEFL LCS SIG Newsletter 23, 9-17.

Muhammed, A.A. (2013). The Effect of Teaching Literature on Learning English Language: A Study on EFS (English as a Foreign Students) and EFL Classes. Interna- 
tional Journal of Advanced Research in Literature and Education, 1(1), 27-38.

Nileson, A., \& Donelson, K. (1980). Literature for Today's Young Adults. Glenview, Illinois, Scott, Foresman and Company.

Obeidat, M. M. (1996). On Non-native Grounds: The Place of American Literature in the English Curriculum of the Arab World Universities. American Studies International, 34(1), 18- 30 .

(1997). Language vs. Literature in English Departments in the Arab World. English Teaching Forum, $35(1), 30$

Ogden C. K., Richards, I. A. (1923). The Meaning of Meaning: A Study of the Influence of Language Upon Thought And of The Science of Symbolism. New York: Harcourt.

Ögeyik, M. C. (2007). Attitudes of the Students in English Language Teaching Programs towards Literature Teaching. Eurasian Journal of Educational Research, (29), $1-27$.

Osborn, T. A. (2000). Critical Reflection and the Foreign Language Classroom. Westport, CT: Bergin and Garvey.

Oster, J. (1989). Seeing with Different Eyes: Another View of Literature in the ESL Classes. TESOL Quarterly, 23(1).

Paesani, K. (2011). Research in Language-Literature Instruction: Meeting the Call for Change. Annual Review of Applied Linguistics, (31), 161-181.

Paley, V. (1990). The Boy Who Would Be A Helicopter. The Uses of Storytelling in the Classroom. Cambridge, MA: Harvard University Press.

Palmer, D.J. (1965). The Rise of English Studies. London: Oxford University Press.

Paran, A. (2008). The Role of Literature in Instructed Foreign Language Learning and Teaching: An Evidence-based Survey. Language Teaching, 41(4), 465-496.

Pardede, P. (2011). Short Stories Use in Language Skills Classes: Students' Interest and Perception. Available at: http://www.researchgate.net/publication

Parkinson, B. \& H. Reid Thomas. (2000). Teaching Literature in a Second Language. Edinburgh: Edinburgh University Press.

Povey, J.F. (1967). Literature in TESOL Programs: The Language and the Culture. TESOL Quarterly, 1(2), 40-46.

(1972). Literature in TESL Programs: The Language and Culture. In H. Allen and R. Campbel (Ed.). Teaching English As Second Language. New York, USA: McGraw Hill.

Raines, S., \& Isbell, R.(1989). Tell It Again. Beltsville, MD: Gryphon House.

Rezanijad, A., Zahra, L. \& Zahra, M. (2015). Down from the Pedestal: Revisiting the Exploit of Literature in EFL Language Classes. International Journal of Applied Linguistics \& English Literature, 4(2), 159-168.

Richards, I. A. (1929). Practical Criticism. London: Routledge.

Richards, J; Rodgers, Th. (2007). Approaches and Methods in Language Teaching. Cambridge: Cambridge University Press.
Rivers, W. M. (1968). Teaching Foreign Language Skills. Chicago: University of Chicago Press

Rosenblatt, L. M. (1995). Literature As Exploration. New York: Modern Language Association of America. (1978). The Reader, the Text, the Poem: The Transactional Theory of the Literary Work. Carbondale: Southern Illinois University Press.

Rosli, T. (1995). Teaching Literature in ESL the Malaysian Context. Kuala Lumpur: Penerbit Universiti Pertanian Malaysia.

Sage, H. (1987). Incorporating Literature in ESL Instruction. New Jersey: Prentice-Hall, Inc.

Salih, M. H. (1986). From language to literature in University English Departments. English Teaching Forum, 27 (2), 25-28.

Sánchez, P. (2008). The Use of Literature with Different Language Levels. English Text Construction. 1(2), 226-238.

Sarac, S. (2003). A Suggested Syllabus for the Teaching of Poetry Course in ELT Departments of Turkey. Unpublished M.A. Thesis. Ankara: Hacettepe University.

Sarıçoban, A. (2004). Using Drama in Teaching Turkish as a Foreign Language, Eurasian Journal of Educational Research, (14), 13-32.

Savvidou, C. (2004). An Integrated Approach to the Teaching of Literature in the EFL Classroom. The Internet TESL Journal (12).

Saussure, F. (1974). Course in General Linguistics. London: Fontana.

Scholes, R. (1989). Protocols of Reading. New Haven, CT: Yale University Press.

Scott, V. M., \& Tucker, H. (2002). SLA and the Literature Classroom: Fostering Dialogues. Boston, MA: Heinle.

Schröder, K. (1977). Literatur im fremdsprachenunterricht. Diesterweg: Frankfurt.

Shaaban, S. S. A. (2015). The Effects of Digital Storytelling, Storytelling and Story Reading on Enhancing Palestinian Ninth Graders' Paragraph Writing Skills. European Journal of Educational Studies, 7(1), 23-34.

Shanahan, D. (1997). Articulating the Relationship Between Language, Literature and Culture: Toward A New Agenda for Foreign Language Teaching and Research. The Modern Language Journal, 81 (2), 164-174.

Shakfa, M. D. A. (2012). Difficulties Students Face in Understanding Drama in English Literature at the Islamic University of Gaza. English Language Teaching, 5(9), 95-103.

Short, K. G. (1992). Researching Intertextuality within Collaborative Classroom Learning Environments. Linguistics and Education, (4), 313-333.

Short, M. (1996). Exploring the language of poems, plays and prose. London: Longman.

Showalter, E. (2002). Teaching Literature. New Jersey: Wiley-Blackwell.

Simon, Sh. (2006). Teaching Literature in ELT/TESOL Classes. New Delhi: Sarup \& Sons.

Simpson, P. (1993). Language, Ideology and Point of View. London: Routledge. 
(1997). Language through Literature. An Introduction. London: Routledge.

Spack, R. (1985). Literature, Reading, Writing, and ESL: Bridging the Gaps. TESOL Quarterly, 19(4), 703-721.

Stephens, Elaine C. and Jean E. Brown (2000). A Hand book of Content Literacy Strategies: 75 Practical Reading and Writing Ideas. US: Rowman \& Littlefield Publishers.

Stevick, E. W. (1976). Memory, Meaning and Method: A View of Language Teaching. Belmont, CA: Heinle.

Swaffar, J. K. (1985). Reading Authentic Texts in A Foreign Language: A Cognitive Model. MLJ, 69, 15-34.

(1999). The Case for Foreign Languages As A Discipline. ADFL Bulletin (30), 6-12.

(1988). Readers, Texts, and Second Languages: The Interactive Processes. MLJ, 72, 123-149.

Swaffar, J. K., Arens, K. M., \& Byrnes, H. (1991). Reading for Meaning. An Integrated Approach to Language Learning. Englewood Cliffs, NJ: Prentice Hall.

Tayebipour, F. (2009). In Defence of Teaching literature to EFL Students in the Era of Globalization. In R. R. L. J. Zhang (Ed.). Englishes and Literatures-in-English in a Globalised World. Singapore: National Institute of Education.

Tasneen, W. (2010). Literary Texts in the Language Classroom: A Study of Teachers' and Students' Views at International Schools in Bangkok. Asian EFL Journal, 12(4), 173-187.

Tehan, P., Yuksel, D., \& Inan, B. (2015). The Place of Literature in An English Language Teaching Program: What Do Students Think About It? The Reading Matrix, $15(2), 45-52$.

Timucin, M. (2001). Gaining Insight into Alternative Teaching Approaches Employed in An EFL literature Class. Revista de Filología y su Didáctica (24), 269-293.

Tomlinson, B. (1985). Language Through Literature and Literature Through Language. EFL Gazette, 9, March.

(1998). And Now for Something Not Completely Different: An Approach to Language Through Literature. Reading in a Foreign Language, 11 (2), 177-189.

(2001). Connecting the Mind: A Multi-dimensional Approach to Teaching Language Through Literature. The English Teacher,4(2)104-114.

Toolan, M. (1998). Language in Literature. An Introduction to Stylistics. London: Edward Arnold.

Topping, D. M. (1968). Linguistics or Literature: An Approach to Language. TESOL Quarterly, 2 (2), 95-100.

Trelease, J. (1996). Have you read to your kids today? Instructor, 105(8), 56-60.
Tunnell, M. O., \& Jacobs, J. S. (1989). Using 'Real' Books: Research Findings on Literature Based Reading Instruction. The Reading Teacher, (42), 470-477.

Ur, P. (1996). A Course in Language Teaching: Practice and Theory. Cambridge: Cambridge University Press.

Van, T.T.M. (2009). The Relevance of Literary Analysis to Teaching Literature in the EFL Classroom. English Teaching Forum, (3), 2-9.

Wales, K. (1989). A Dictionary of Stylistics. London: Longman.

Wellek, R. \& A. Warren. (1994). Theory of Literature. Harcourt, Brace and Company

Wells, G. (1990). Talk About Text: Where Literacy Is Learned and Taught. Curriculum Inquiry, (20), 369-405.

Weber, J. J. (1996). The Stylistics Reader. From Roman Jakobson to the Present. London: Edward Arnold.

Whitehead, R. (1968). Children's Literature: Strategies of Teaching. Englewood Cliffs, NJ: Prentice- Hall Inc.

Whiteson, Valerie (1996). New Ways of Using Drama and Literature in Language Teaching. Alexandria, VA., TESOL.

Widdowson, H. G. (1975). Stylistics and the Teaching of Literature. Oxford: Oxford University Press.

(1983). Talking Shop: Literature and ELT. ELT Journal, 37(1), 30-36.

(1984). Stylistics and the Teaching of Literature. Essex, UK: Longman.

(1992). Practical Stylistics. Oxford: Oxford University Press.

(1994). Teaching Language as Communication. Oxford: Oxford University Press.

Yadav, S. (2014). Recognizing the Importance of Literature and Integration in ELT Classes. International Journal of Education and Research, 2(9), 393-400.

Yarahmadi, A. M. (2016). Incorporating Literature for Fostering EFL Learners' Literary Competence. International Journal of Research in Linguistics, Language Teaching and Testing, 1(5), 236-244

Yilmaz, C. (2012). Introducing Literature to an EFL Classroom: Teacher's Instructional Methods and Students' Attitudes toward the Study of Literature. English Language Teaching. 5(1), 86-99.

Yopp, R. H., \& Yopp, H. K. (2009). Literature-Based Reading Activities. Boston: Allyn \& Bacon.

Yuksel, D. (2007). The Nature of Discussions in An Advanced-level Literature Course in a Turkish EFL setting (Unpublished doctoral dissertation). Tallahassee: Florida State University.

Zid, Munir Ben. (2015). Arab Students' Perspective on the Value of Literature. Theory and Practice in Language Studies, 5(5), 927-933. 